\title{
LICHENS AS BIOLOGICAL INDICATORS OF AIR QUALITY IN THE URBAN AREA OF KURŠUMLIJA (SOUTHERN SERBIA)
}

\author{
Svetlana S. Ristićc ${ }^{*}$, Marijana M. Kosanić ${ }^{1}$, Branislav R. Ranković ${ }^{1}$, \\ Slaviša S. Stamenkovič́ \\ ${ }^{1}$ University of Kragujevac, Faculty of Science, Department of Biology, \\ Radoja Domanovića 12, 34000 Kragujevac, Republic of Serbia \\ ${ }^{2}$ University of Niš, Faculty of Sciences and Mathematics, Department of Biology and Ecology, \\ Višegradska 33, 18000 Niš, Republic of Serbia \\ *Corresponding author; E-mail address: risticsvetlanaaa@ gmail.com
}

(Received April 26, 2016; Accepted September 5, 2016)

\begin{abstract}
In this work, we provided a first indication of Kuršumlija (town of Southern Serbia) air quality using epiphytic lichens known as bioindicators. The investigations were carried out from April to October 2014. The analysis of thalli samples (from 15 investigated points in Kuršumlija), indicates the presence of 42 lichens taxa from 23 genera. An assessment of air quality was made by using the Index of Atmospheric Purity (IAP) and Index of Human Impact (IHI). IHI values ranged between 15 and 36. IAP values ranged between 10 and 28. According to the IAP values, it has been found that there are three different air pollution zones: "normal", "struggle" and "lichen desert". The latest characterize the majority of the urban area. The aim of this study is to formulate an indication of air quality using lichens as bioindicators on the basis of lichens diversity and frequency. This is of great importance because there are no continuous physical and chemical measurements of air quality in this area.
\end{abstract}

Key words: air quality, bioindication, lichens.

\section{INTRODUCTION}

Deterioration of air quality is noticeable worldwide. Air pollution is an essential problem in many urban areas in the world (EEA, 2014). European citizens often breathe air that does not meet European standards (EEA, 2014). Effects of air pollution are especially expressed in urban areas where there are the main sources of pollution (traffic, industry, anthropogenic activity etc.). Air pollution is the top environmental risk factor of premature death in Europe. Especially, it increases the incidence of a wide range of diseases and has many environmental impacts, damaging not only the population but also the vegetation and the ecosystem (EEA, 2014).

Lichens are cosmopolite, symbiotic organisms composed of fungi and photosynthetic organisms (generally green algae and cyanobacteria). About 17,000-25,000 species of known lichens species grow on Earth according to various estimations (cf. KIRK et al., 2001; CHAPMAN, 2009). Lichens have a wide variety of proven and potential applications, that range 
from their use as bioindicators to their use as possible sources of many bioactive compounds (KOSANIĆ and RANKOVIĆ, 2011).

The use of lichens as bioindicators provides a special viewpoint on the atmospheric environment (NIMIS et al., 2002) and different bioindication methods are available based on their specific response (PAOLI et al., 2015). A large number of species of these unique organisms is characterized by a great sensitivity to the impact of air pollution and for this reason, they can be used as indicators of air pollution.

Several studies have focused on the effect of pollution on urban areas (GOMBERT et al., 2004; Washburn and CUlley, 2006; Blasco et al., 2008; CALVElo et al., 2009; KAEFFER et al., 2011; STAMENKOVIĆ et al., 2013a), using lichens as bioindicators especially in the southern and southeastern Serbia (CVIJAN and STAMENKović, 1996; STAMENKović, 1997; PejČInović, 2000; Stamenković and CVijan, 2002; Stamenković and CVIJAN, 2003; Stamenković and CVijan, 2004; Stamenković and CVijan, 2010; Stamenković et al., 2010; STAMENKOVIĆ et al., 2012; STAMENKOVIĆ et al., 2013a; STAMENKOVIĆ et al., 2013b).

The aim of this investigation is to (i) present the results of the air quality in an urban ecosystem and (ii) contribute to the knowledge in biogeography and diversity of lichens in the Republic of Serbia and (iii) create the basis for the evaluation of lichens as indicators of the investigated urban territory.

\section{MATERIALS AND METHODS}

\section{Study area}

This work was carried out in Kuršumlija (population 13,306, area of c. $952 \mathrm{~km}^{2}$, SORS 2011), an urban area of Southern Serbia. Kuršumlija is a town located at an altitude of $383 \mathrm{~m}$ (above the sea level). The climate is moderate continental. The most frequent (prevailing) wind blows from the southwest direction of $310 \%$, followed by north $171 \%$ and the northeast direction $162 \%$. The "wind roses" in Kuršumlija area provides a graphical representation of these data (Fig. 1). The mean annual temperature is $11.6{ }^{\circ} \mathrm{C}$. This value presents monthly average value for the year of 2014 . The relative air humidity was $79 \%$. The mean annual rainfall is $968.3 \mathrm{~mm}$, which is much higher than in the surrounding towns (RHSS, 2014). The study area encompasses the urban part of Kuršumlija and a few agricultural fields remaining on the periphery of the city.

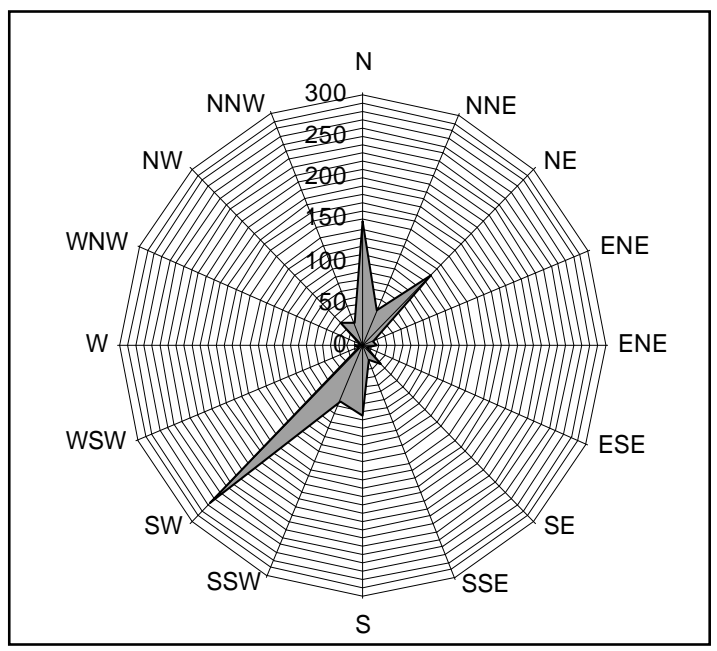

Figure 1. "Wind roses" in Kuršumlija area (RHSS, 2014). 


\section{Sample collection}

The investigation was done from May 21 to September 8 in the year of 2014 . Epiphytic lichens are determined and collected from the bark of various species of trees at 1.5-2.0 $\mathrm{m}$ above the ground, exclusively from the trunks angled no higher than $5^{\circ}$. The 15 investigated points were located exclusively in urban part of the in Kuršumlija town.

Lichen samples requiring microscopic observations were collected, cleared of substrate and then identified in the laboratory. Determining the essential characters of lichens was conducted using laboratory magnifying glass brand "PZO" (maximum magnification 85x, 10x minimum), and the light microscope brand "Biolam S-11" with the possibility of a maximum magnification of $1350 x$.

The voucher specimens of the lichens were determined and deposited in the lichenological herbarium of the Department of Biology and Ecology, Faculty of Science, University of Kragujevac, Republic of Serbia.

A few literature sources were used for identification of the collected lichen species (WIRTH, 1995; DOBSON, 2005), as well as indexfungorum.org and mycobank.org for arrangement of list of species.

\section{Indication method description}

The method of lichen indication of air quality consists of detecting, collecting, identifying and mapping the species and calculation of the Index of Atmospheric Purity (IAP). In this research the numeric method known as the Index of Atmospheric Purity - IAP (PIRINTSOS et al., 1993; KRICKE and LOPPI, 2002) was calculated for each of investigated points:

$$
\mathbf{I A P}=\Sigma \boldsymbol{f}
$$

where: $\boldsymbol{f}=$ coefficient which represents the frequency and the cover of each species studied within the surveyed area.

We also used method Index of Human Impact - IHI (GOMBERT et al., 2004), which was proposed to characterize each investigated point by means of environmental parameters.

$$
\mathbf{I H I}=\mathbf{U}(\mathbf{T}+\mathbf{D}+\mathbf{E})
$$

where: $\mathbf{U}=$ urbanization (urban, suburban or rural areas); $\mathbf{T}=$ traffic (distance from a road); $\mathbf{D}=$ local developments (crop fields, green areas, housing sites, car parks); $\mathbf{E}=$ exposure (trees isolated, in rows or grouped).

Categories (' 1 ' and ' 4 ') were established for each parameter to express a gradient of alteration (Tab. 1). IHI was calculated for each investigated point.

The aim of using these methods is to detect and quantify atmospheric pollution. 
Table 1. Assessment of quantitative variables from general qualitative environmental variables (urbanization, traffic and local developments) by an increase of artificiality and from local environmental conditions (exposure) (GOMBERT et al., 2004).

\begin{tabular}{|c|c|c|}
\hline Parameters & & \\
\hline \multirow[t]{2}{*}{ Urbanization (U) } & Rural & Sub-urban and Urban \\
\hline & 1 & 4 \\
\hline \multirow{2}{*}{ Traffic (T) } & Weak road exposure & High road exposure \\
\hline & 1 & 4 \\
\hline \multirow[t]{2}{*}{ Local developments (D) } & Crop fields, Green areas & $\begin{array}{l}\text { Housing sites, } \\
\text { Car parks, and roads }\end{array}$ \\
\hline & 1 & 4 \\
\hline \multirow[t]{2}{*}{ Exposure (E) } & Trees isolated or in rows & Trees grouped \\
\hline & 1 & 4 \\
\hline
\end{tabular}

\section{RESULTS AND DISCUSSION}

Many authors in world have assessed air pollution effects indicated by epiphytic lichens in urban areas (PINHO et al., 2008; 2009; PERLMUTTER, 2010; MunZI et al., 2014; PAOLI et al., 2015). Our work is the modest contribution to this type of research carried out in Southern Serbia.

The research on 15 investigated points in Kuršumlija revealed the presence of 42 lichens taxa, from 23 genera:

Amandinea punctate (Hoffm.) Coppins \& Scheid.

Candelariella vitelline (Hoffm.) Müll. Arg.

Candelariella xanthostigma (Ach.) Lettau

Evernia prunastri (L.) Ach.

Flavoparmelia caperata (L.) Hale

Graphis scripta (L.) Ach.

Hypogymnia physodes (L.) Nyl.

Hypogymnia tubulosa (Schaerer) Havaas

Lecanora allophana (Ach.) Nyl.

Lecanora argentata (Ach.) Malme

Lecanora carpinea (L.) Vain

Lecanora intumescens (Rebent.) Rabenh.

Lecanora pulicaris (Pers.) Ach.

Lecidella elaeochroma (Ach.) Choisy

Lepraria aeruginosa (F.H. Wigg.) Sm.

Lepraria incana (L.) Ach.

Melanohalea exasperate (De Not.) O. Blanco, A. Crespo, Divakar, Essl., D. Hawksw. \& Lumbsch

Melanohalea exasperatula (Nyl.) O. Blanco, A. Crespo, Divakar, Essl., D. Hawksw. \& Lumbsch

Melanelixia fuliginosa (Fr. ex Duby) O.Blanco, A. Crespo, Divakar, Essl., D. Hawksw. \& Lumbsch

Melanelixia glabra (Schaer.) O. Blanco, A. Crespo, Divakar, Essl., D. Hawksw. \& Lumbsch

Melanelixia subaurifera (Nyl.) O. Blanco, A. Crespo, Divakar, Essl., D. Hawksw. \& Lumbsch

Melanelixia subargentifera (Nyl.) O. Blanco, A. Crespo, Divakar, Essl., D. Hawksw. \& Lumbsch

Ochrolechia pallescens (L.) Massal.

Parmelia saxatilis (L.) Ach.

Parmelia sulcate Taylor 
Parmelia tiliacea (Hoffm.) Hale

Parmelina pastilifera (Harm.) Hale

Parmeliopsis ambigua (Wulfen) Nyl.

Phaeophyscia orbicularis (Neck.) Moberg

Physcia adscendens (Fr.) H. Olivier

Physcia aipolia (Ehrh. ex Humb.) Fürnr.

Physcia semipinnata (Leers ex J.F. Gmel.) Moberg

Physcia stellaris (L.) Nyl.

Physcia tenella (Scop.) DC.

Physconia distorta (With.) J.R. Laundon

Physconia enteroxantha (Nyl.) Poelt

Physconia grisea (Lam.) Poelt

Pseudevernia furfuracea (L.) Zopf

Ramalina farinacea (L.) Ach.

Usnea hirta (L.) Weber ex F.H. Wigg.

Xanthoparmelia stenophylla (Ach.) Ahti \& D. Hawksw.

Xanthoria parietina (L.) Beltr.

The most frequent species (100\%) were Hypogymnia physodes and Physcia adscendens (Tab. 2). Parmelia sulcata and Xanthoria parietina were characterized by frequencies of $93.33 \%$. The rarest were Lepraria sp. and Xanthoparmelia stenophylla, which were found at only one of investigated localities, with a low frequency of $6.67 \%$. Lichens were found mostly on different tree species - Acer campestre L., Cornus mas L., Juglans regia L., Malus domestica Borkh., Robinia pseudoacacia L., Tilia platyphyllos Scop. etc.

The calculated IAP values ranged between 10 and 28. IHI values ranged between 15 and 36 (Tab. 2). Based on calculated IAP, we established the distribution of the different air pollution zones in Kuršumlija (Fig. 2). The urban area of Kuršumlija includes all air quality zones: "lichen desert" zone, "struggle zone" and "normal zone".

The presence of "lichen desert" zone indicates a high level of air pollution. The "lichen desert" zone included two investigated points (3 and 4) collocated in the central part of this urban ecosystem. These investigated points are characterized by low diversity of lichens and the lowest values of IAP. Lichen "struggle zone" included three investigated points (7, 8 and 9). The air quality is slightly better in this zone than in the previous one. It indicates that the air is moderately polluted in this zone. The greatest part of the town belongs to "normal zone". This zone included ten investigated points $(1,2,5,6,10,11,12,13,14$ and 15). Lichen species noticed on these investigated points are distinguished by the higher diversity and IAP values.

Distribution of zones of different air pollution levels in the investigated area are a logical consequence of air pollution and the mutual influence of microclimate, substrate and geophysical features, as well as the type and distribution of urban areas and objects. The sources of air pollution in the town are relatively developed traffic in the centre of town and individual stakeholders. The Kuršumlija once had developed wood, textile and metal industry, which, which after a few decades of economic crisis got into a difficult situation and stopped working. Green areas are the best locations for lichens, therefore their diversity is the highest in the outskirts of town. Domestic activity, compared with the urbanization, may have some impact, but it can be almost negligible when compared to traffic (LLOP et al., 2012). The lower lichen diversity in urban areas, is probably due to the drier city microclimate, compared to those of the rural and natural sites (LLOP et al., 2012). 


\section{CONCLUSION}

Kuršumlija is a small European town in Southern Serbia, without developed industry. Bioindication and physicochemical investigation of air pollution in Kuršumlija has not been done until now.

The method used in this research provides an insight into the quality of the air on investigated area by calculating IAP based on the lichen diversity and abundance. According to the calculated IAP values, we created the zones-map of different air pollution levels. The results indicate that it is necessary to reduce traffic in the downtown, redirect vehicles to transit routes which might contribute to improvement of air quality.

Our further investigations will be attended to the long-term air quality monitoring at local and regional level.

This work is a mere contribution to the biomonitoring of air pollution, i.e. air quality of Southern Serbia. Moreover, this work represents the only lichenological research conducted in this area.

\section{References:}

[1] Blasco, M., Domeno, C., Nerin, C. (2008): Lichens biomonitoring as feasible methodology to assess air pollution in natural ecosystems: combined study of quantitative PAHs analyses and lichen biodiversity in the Pyrenees Mountains. Analytical and Bioanalytical Chemistry 391: 759-771.

[2] Calvelo, S., Baccala, N., Liberatore, S. (2009): Lichens as bioindicators of air quality in distant areas in Patagonia (Argentina). Environmental Bioindicators 4: 123135.

[3] Chapman, A.D. (2009): Numbers of living species in Australia and the world. Australian Biological Resources Study (ABRS). Canberra. 80 pp.

[4] Cvijan, M., Stamenković, S. (1996): Bioindication of air pollution in the Niš area by use of lichens. Ekologija 31: 151-157.

[5] Dobson, F.S. (2005): Lichens. Richmond, Richmond Publishing Co. Ltd.

[6] EEA, (2014): Air quality in Europe-2014 report, EEA Technical Report No 5/2014, European Environment Agency.

[7] Gombert, S., Asta, J., Seaward, M.R.D. (2004): Assessment of lichen diversity by index of atmospheric purity (IAP), index of human impact (IHI) and other environmental factors in an urban area (Grenoble, southeast France). Science of the total environment 324: 183-199.

[8] Käffer, M.I., de Azevedo Martins, S.M., Alves, C., Pereira, V.C., Fachel, J., FERRÃO VARGAS, V.M. (2011): Corticolous lichens as environmental indicators in urban areas in southern Brazil. Ecological Indicators 11: 1319-1332.

[9] Kirk, P.M., CAnnon, P.F., David, J.C. És StalPers, J.A. (2001): Ainsworth \& Bisby's dictionary of the fungi. Ninth Edition. - CAB International, Egham, 655 pp. 
[10] Kosanić, M., Ranković, B. (2011): Lichens as possible sources of antioxidants. Pakistan Journal of Pharmaceutical Sciences 24: 165-170.

[11] KrICKE, R., LOPPI, S. (2002): Bioindication: the IAP approach. In: Nimis, P., Scheidegger, C. \& Wolseley, P. (Eds.) Monitoring with Lichens - Monitoring Lichens. Dordrecht, Kluwer Academic.

[12] Llop, E., Pinho, P., Matos, P., Pereira, M.J., Branquinho, C. (2012): The use of lichen functional groups as indicators of air quality in a Mediterranean urban environment. Ecological indicators 13: 215-221.

[13] Munzi, S., Correia, O., Silva, P., Lopes, N., Freitas, C., Branquinho, C., Pinho, P. (2014): Lichens as ecological indicators in urban areas: beyond the effects of pollutants. Journal of Applied Ecology 51: 1750-1757.

[14] Nimis, P.L., Scheidegger, C., Wolseley, P.A. (2002): Monitoring with Lichens Monitoring Lichens. NATO Science Series. Kluwer Academic Publishers, Dordrecht, The Netherlands.

[15] Paoli, L., Munzi, S., Guttová, A., Senko, D., Sardella, G., Loppi, S. (2015): Lichens as suitable indicators of the biological effects of atmospheric pollutants around a municipal solid waste incinerator (S Italy). Ecological Indicators 52: 362-370.

[16] Pejčinović, D., Bogdanović-Dušanović, G., Dušanović, D. (2000): Lišajna flora Vranja i uže okoline. Zbornik radova 6. Simpozijum o flori jugoistočne Srbije i susednih područja, Sokobanja, 4.-7. jul 2000: 39- 41.

[17] Perlmutter, G.B. (2010): Bioassessing air pollution effects with epiphytic lichens in Raleigh, North Carolina, USA. Bryologist 113: 39-50.

[18] Pinho, P., Augusto, S., Martins- Loucão, M.A., Pereira, M.J., Soares, A., Maguas, C., BRANQUinho, C. (2008): Causes of change in nitrophytic and oligotrophic lichen species in a Mediterranean climate: impact of land cover and atmospheric pollutants. Environmental Pollution 154: 380-389.

[19] Pinho, P., Branquinho, C., Cruz, C., Sim Tang, Y., Dias, T., Rosa, A.P., Máguas, C., Martins-Loucão, M.A. (2009): Assessment of critical levels of atmospheric ammonia for lichen diversity in cork-oak woodland Portugal. In: Sutton, M., Reis, S., Baker, S. (Eds.) Atmospheric Ammonia. Springer Science + Business Media, New York - Heidelberg, 109-120 pp.

[20] Pirintsos, S.A., Vokou, D., Diamantopoulos, J., Galloway, D.J. (1993): An assessment of the sampling procedure for estimating air pollution using epiphytic lichens as indicators. Lichenologist 25: 165-173.

[21] RHSS, (2014): Republic Hydrometeorological Service of Serbia.

[22] SORS, 2011: 2011 Census of Population, Households and Dwellings on the ethnicity of the population of the Republic of Serbia, Statistical Office of the Republic of Serbia.

[23] STAMENKOVIĆ, S. (1997): Biological indication of air pollution in Prokuplje by means of lignicolous lichens. Ekologija 32: 107-110.

[24] Stamenković, S., Cvijan, M. (2002): Epiphytic lichens as bioindicator of air quality in Leskovac (southern Serbia). Ekologija 37: 41-46.

[25] Stamenković, S., Cvijan, M. (2003): Bioindication of air pollution in Niš by using epiphytic lichens. Archive of Biological Sciences 55: 133-140. 
[26] Stamenković, S., Cvijan, M. (2004): Using of epiphytic lichens for bioindication of air pollution in Vranje. Archive of Biological Sciences 56: 139-143.

[27] Stamenković, S., Cvijan, M. (2010): Determination of air pollution zones in Knjaževac (southeastern Serbia) by using epiphytic lichens. Biotechnology and Biotechnological equipment, special edition-online (2nd Balkan Conference on Biology, Plovdiv, Bulgaria: 278-283.

[28] StAmenković, S., CvijAn, M., ARANĐElović, M. (2010): Lichen as bioindicators of air quality in Dimitrovgrad (southeastern Serbia). Archive of Biological Sciences 62: 643648.

[29] Stamenković, S., Đekić, T., Mitrović, T., Stojičić, D., Cvetković, V., Nikolić, M. (2012): Monitoring of air quality and ,"lichen desert“" in the city of Leskovac (southeastern Serbia) in the period 2000-2011, Abstract book, IV congress of ecologists of the Republic of Macedonia with international participation, $106 \mathrm{p}$, Skoplje, Makedonija (FYRM).

[30] Stamenković, S., Ristić, S., Đekić, T., Mitrović, T., BaOšić, R. (2013a): Air quality indication in Blace (Southeastern Serbia) using lichens as bioindicators. Archive of Biological Sciences 65: 893-897.

[31] Stamenković, S., Mitrović, T., Cvetković, V., Krstić, N., Baošić, R., Marković, M., Nikolić, N., Marković, V., CVIJAN, M. (2013b): Biological indication of heavy metal pollution in the areas of Donje Vlase and Cerje (southeastern Serbia) using epiphytic lichens. Archive of Biological Sciences 65: 151-159.

[32] WASHBURN, SJ., CULLEY, TM. (2006): Epiphytic macrolichens of the greater Cincinnati metropolitan area - part II: distribution, diversity and urban ecology. Bryologist 109: 516-526.

[33] WIRTH, V. (1995): Die Flechten Baden-Wurtembergs. Verbreitungsatlas, 1 \& 2. 
Table 2. Lichen species found on the researched area, the values of the coefficient $\mathbf{f}$, the frequency (\%) of each taxon and values of IAP and IHI on each of investigated points in Kuršumlija.

\begin{tabular}{|c|c|c|c|c|c|c|c|c|c|c|c|c|c|c|c|c|}
\hline Investigated point & 1 & 2 & 3 & 4 & 5 & 6 & 7 & 8 & 9 & 10 & 11 & 12 & 13 & 14 & 15 & $\%$ \\
\hline Amandinea punctata & 0 & 1 & 0 & 0 & 1 & 0 & 1 & 0 & 1 & 0 & 0 & 0 & 0 & 0.3 & 0 & 33.33 \\
\hline Candelariella vitellina & 0 & 0 & 0 & 0 & 1 & 0.4 & 0 & 0 & 0 & 0 & 0 & 0 & 0 & 0 & 0.4 & 20.00 \\
\hline Candelariella xanthostigma & 1 & 0.3 & 0 & 0 & 1 & 1 & 1 & 0 & 0 & 1 & 0 & 1 & 1 & 1 & 0 & 60.00 \\
\hline Evernia prunastri & 2 & 2 & 0 & 0 & 2 & 1 & 0 & 1 & 0 & 2 & 2 & 1 & 2 & 1 & 2 & 73.33 \\
\hline Flavoparmelia caperata & 1 & 1 & 0 & 0 & 0 & 0.4 & 0 & 0.4 & 0 & 0 & 1 & 0 & 1 & 1 & 1 & 53.33 \\
\hline Graphis scripta & 0 & 0 & 0 & 0 & 0 & 1 & 0 & 0.3 & 0 & 0 & 0 & 0 & 1 & 0 & 0.4 & 26.67 \\
\hline Hypogymnia physodes & 3 & 3 & 1 & 1 & 3 & 2 & 1 & 1 & 2 & 2 & 2 & 1 & 2 & 2 & 2 & 100.00 \\
\hline Hypogymnia tubulosa & 1 & 0 & 0 & 0 & 1 & 0 & 0 & 0 & 1 & 0.4 & 1 & 0 & 1 & 1 & 1 & 53.33 \\
\hline Lecanora allophana & 0 & 0 & 0 & 0 & 0 & 0 & 0 & 0.4 & 1 & 0 & 0 & 0 & 0 & 0 & 0.3 & 20.00 \\
\hline Lecanora argentata & 0 & 0 & 0 & 0 & 1 & 0.4 & 1 & 0 & 0 & 0 & 0 & 0 & 0 & 0 & 0 & 20.00 \\
\hline Lecanora carpinea & 0 & 1 & 0 & 0.3 & 0 & 1 & 0 & 0 & 0 & 0.4 & 0 & 0 & 1 & 0 & 0.3 & 40.00 \\
\hline Lecanora intumescens & 0 & 0 & 0 & 0.3 & 0 & 1 & 0 & 0.3 & 0 & 1 & 1 & 0.4 & 0 & 0.3 & 1 & 53.33 \\
\hline Lecanora pulicaris & 0 & 0 & 0 & 0 & 1 & 0 & 0.4 & 0 & 0 & 0 & 0.4 & 1 & 0 & 0.3 & 0 & 33.33 \\
\hline Lecidella elaeochroma & 0 & 1 & 0 & 0.1 & 0 & 0 & 1 & 0 & 0 & 1 & 1 & 1 & 1 & 1 & 0 & 53.33 \\
\hline Lepraria aeruginosa & 0 & 1 & 0 & 0 & 0 & 0 & 0 & 0 & 0 & 0 & 0 & 0 & 0 & 0 & 0 & 6.67 \\
\hline Lepraria incana & 1 & 0 & 0 & 0 & 0 & 0 & 0 & 0 & 1 & 0 & 1 & 1 & 0 & 0 & 0 & 26.67 \\
\hline Melanohalea exasperata & 0 & 0 & 0 & 0 & 0 & 0 & 0 & 0 & 1 & 1 & 0 & 0 & 0 & 1 & 0 & 20.00 \\
\hline Melanohalea exasperatula & 1 & 0 & 0 & 0 & 0 & 0 & 0 & 0 & 0 & 1 & 1 & 1 & 0 & 0 & 0 & 26.67 \\
\hline Melanelixia fuliginosa & 0 & 0 & 0 & 0 & 0 & 0 & 0 & 0 & 0 & 0 & 0 & 1 & 1 & 0 & 1 & 20.00 \\
\hline Melanelixia glabra & 0 & 0 & 0 & 0 & 0 & 0.4 & 0 & 0 & 1 & 1 & 1 & 1 & 0 & 1 & 0 & 40.00 \\
\hline Melanelixia subaurifera & 2 & 2 & 1 & 1 & 2 & 1 & 2 & 0 & 2 & 2 & 2 & 1 & 1 & 0 & 2 & 86.67 \\
\hline Melanelixia subargentifera & 0 & 0 & 0 & 0 & 0 & 0 & 0 & 0 & 1 & 0.4 & 0.4 & 1 & 0 & 0 & 0.3 & 33.33 \\
\hline Ochrolechia pallescens & 0 & 0 & 0 & 1 & 0.1 & 0 & 1 & 0.4 & 1 & 0 & 1 & 1 & 1 & 0 & 0.3 & 60.00 \\
\hline Parmelia saxatilis & 0 & 0 & 0 & 0 & 0 & 0 & 0 & 0.4 & 0 & 0 & 0 & 0 & 1 & 0 & 0 & 13.33 \\
\hline
\end{tabular}


Continuation of Table 2. Lichen species found on the researched area, the values of the coefficient $\mathbf{f}$, the frequency (\%) of each taxon and values of IAP and IHI on each of investigated points in Kuršumlija.

\begin{tabular}{lcccccccccccccccc}
\hline \multicolumn{1}{c}{ Investigated point } & $\mathbf{1}$ & $\mathbf{2}$ & $\mathbf{3}$ & $\mathbf{4}$ & $\mathbf{5}$ & $\mathbf{6}$ & $\mathbf{7}$ & $\mathbf{8}$ & $\mathbf{9}$ & $\mathbf{1 0}$ & $\mathbf{1 1}$ & $\mathbf{1 2}$ & $\mathbf{1 3}$ & $\mathbf{1 4}$ & $\mathbf{1 5}$ & $\mathbf{\%}$ \\
Taxon & & & & & & & & & & & & & & \\
\hline Parmelia sulcata & 3 & 2 & 1 & 0 & 2 & 2 & 2 & 2 & 2 & 3 & 2 & 2 & 2 & 3 & 2 & 93.33 \\
Parmelia tiliacea & 0 & 0 & 0 & 0 & 1 & 0.3 & 0 & 0 & 0 & 0 & 1 & 1 & 1 & 1 & 1 & 46.67 \\
Parmelina pastilifera & 0 & 0 & 0 & 0 & 0 & 0 & 0 & 0 & 0 & 0.1 & 1 & 0.3 & 1 & 1 & 0.4 & 40.00 \\
Parmeliopsis ambigua & 0 & 0 & 0 & 0 & 0 & 0 & 0 & 1 & 0 & 1 & 0 & 0 & 0.4 & 0 & 0 & 20.00 \\
Phaeophyscia orbicularis & 0 & 2 & 0 & 2 & 2 & 1 & 2 & 2 & 1 & 2 & 2 & 1 & 2 & 2 & 1 & 86.67 \\
Physcia adscendens & 3 & 2 & 2 & 2 & 2 & 2 & 1 & 2 & 2 & 1 & 3 & 2 & 2 & 2 & 1 & 100.00 \\
Physcia aipolia & 1 & 0 & 1 & 0 & 1 & 1 & 1 & 1 & 1 & 1 & 0 & 1 & 0 & 1 & 1 & 73.33 \\
Physcia semipinnata & 0 & 0 & 0 & 0 & 0 & 0 & 0 & 0 & 0 & 0 & 0 & 0.4 & 0.4 & 0 & 0 & 13.33 \\
Physcia stellaris & 0 & 0 & 0 & 1 & 0 & 1 & 0 & 0 & 1 & 1 & 0 & 1 & 1 & 0.3 & 0.4 & 53.33 \\
Physcia tenella & 0 & 1 & 0 & 0 & 1 & 0.4 & 0 & 0 & 1 & 0.1 & 0 & 0.4 & 0 & 0 & 0 & 40.00 \\
Physconia distorta & 0 & 0 & 0 & 0 & 0 & 0 & 0 & 0 & 0 & 0.1 & 0 & 1 & 1 & 0.4 & 0.4 & 33.33 \\
Physconia enteroxantha & 0 & 1 & 0 & 0 & 0 & 0 & 0 & 0.3 & 0 & 0 & 0 & 1 & 1 & 1 & 1 & 40.00 \\
Physconia grisea & 2 & 1 & 1 & 1 & 0 & 1 & 1 & 1 & 0 & 1 & 0 & 2 & 0 & 2 & 1 & 73.33 \\
Pseudevernia furfuracea & 1 & 0 & 0 & 0 & 0 & 0.3 & 0 & 0 & 0 & 0.3 & 0 & 0 & 0.4 & 0.3 & 1 & 40.00 \\
Ramalina farinacea & 0 & 0 & 0 & 0 & 0 & 0.4 & 0 & 1 & 0 & 0.1 & 0 & 0 & 0.4 & 0 & 0 & 26.67 \\
Usnea hirta & 0 & 0 & 0 & 0 & 0 & 1 & 0 & 0 & 0 & 0.1 & 0 & 0.4 & 0 & 0 & 0 & 20.00 \\
Xanthoparmelia stenophylla & 0 & 0 & 0 & 0 & 0 & 1 & 0 & 0 & 0 & 0 & 0 & 0 & 0 & 0 & 0 & 6.67 \\
Xanthoria parietina & 4 & 3 & 3 & 1 & 2 & 2 & 3 & 2 & 1 & 1 & 0 & 2 & 2 & 1 & 1 & 93.33 \\
\hline Index of Atmospheric Purity (IAP) & $\mathbf{2 8}$ & $\mathbf{2 3}$ & $\mathbf{1 0}$ & $\mathbf{1 1}$ & $\mathbf{2 4}$ & $\mathbf{2 1}$ & $\mathbf{1 4}$ & $\mathbf{1 6}$ & $\mathbf{1 8}$ & $\mathbf{2 2}$ & $\mathbf{2 2}$ & $\mathbf{2 4}$ & $\mathbf{2 6}$ & $\mathbf{2 1}$ & $\mathbf{2 2}$ \\
\hline \multicolumn{1}{c}{ Index of Human Impact $(\mathrm{IHI})$} & $\mathbf{1 8}$ & $\mathbf{2 4}$ & $\mathbf{3 6}$ & $\mathbf{3 2}$ & $\mathbf{2 4}$ & $\mathbf{2 1}$ & $\mathbf{3 6}$ & $\mathbf{2 8}$ & $\mathbf{2 8}$ & $\mathbf{2 1}$ & $\mathbf{2 1}$ & $\mathbf{1 5}$ & $\mathbf{1 5}$ & $\mathbf{1 8}$ & $\mathbf{1 8}$ \\
\hline
\end{tabular}




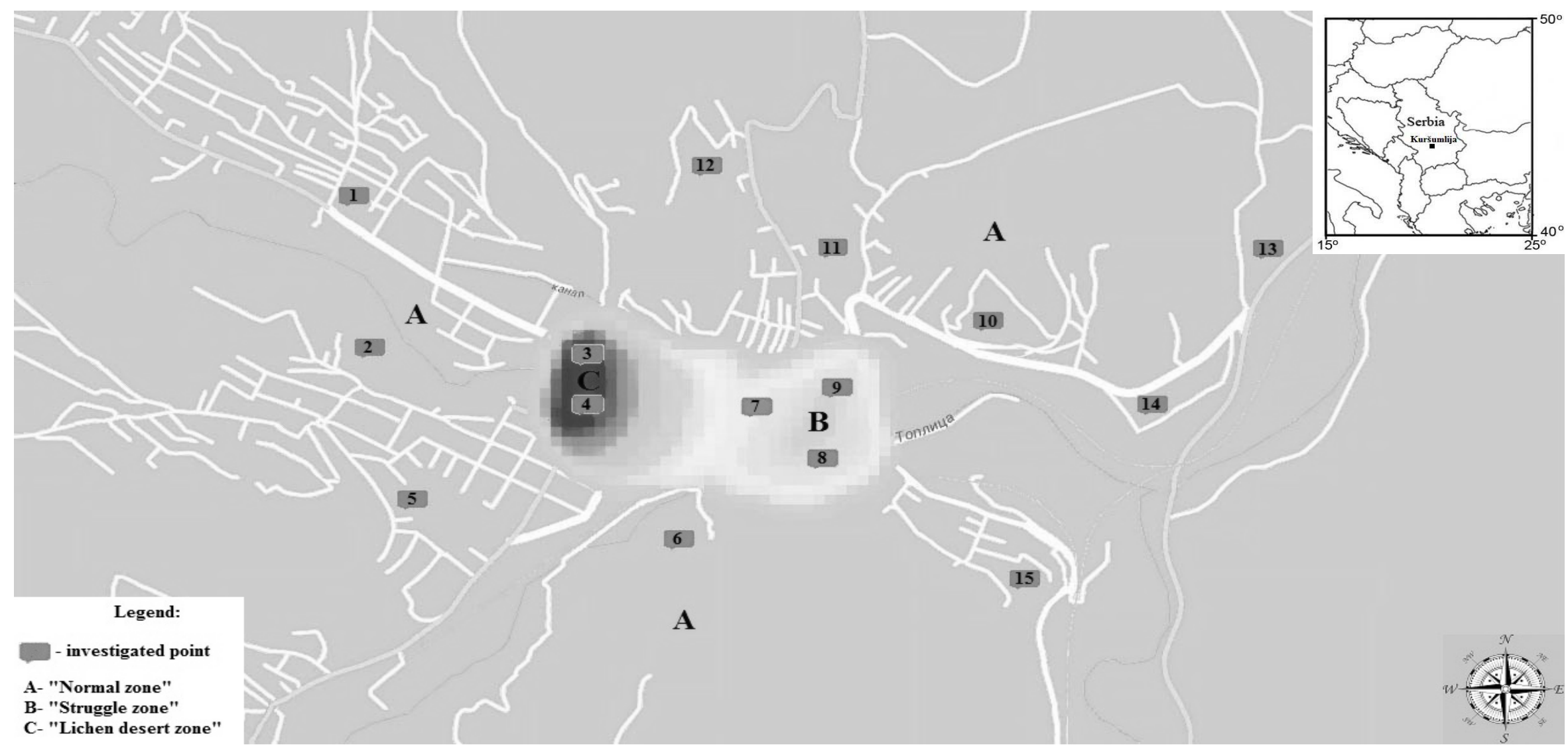

Figure 2. Zones of different levels of air pollution in Kuršumlija defined by using lichens as bioindicators. 